\title{
Questioning our actions: conversations around the politics of collective embroidery across space and time
}

\author{
Authors: Danielle House $\vee$, University of Reading, UK, Cordelia Rizzo $\vee$, Northwestern \\ University, United State, Rosa Borrás $\vee$, Independent Artist, Mexico
}

Danielle House is a postdoctoral research associate at the University of Reading, researching cemeteries and crematoria as public spaces of belonging. Her PhD was completed at the Department of International Politics at Aberystwyth University, researching the memory and memorialisation of people disappearing in contemporary Mexico, and relative-led searches for them.

Rosa Borrás is a visual artist, printmaker, and embroiderer in Mexico City. She has exhibited in 23 solo shows and 55 group shows in Mexico and abroad. She was the coordinator of Bordando por la Paz Puebla (2012-2019), an independent cultural promoter, and dollmaker, interested in art and Human Rights.

Cordelia Rizzo is a Mexican activist, scholar, and maker. She is a PhD Candidate in Performance Studies from Northwestern University and holds an MA in Philosophy from KU Leuven. Her research probes the language of textile making related to the search for the disappeared in Mexico to theorize what makes memory work possible.

\begin{abstract}
Embroidery has been used by communities to testify to violence for many years but these experiences were often marginalised. A recent proliferation of international textile responses to such crises, however, and a visibilisation of textiles in general, have been enabled through social media. This contribution reflects on a Whatsapp conversation across space and time between friends, who have been participating in personal and collective embroidery projects. In this piece, we wish to reveal the role of conversation and its relationship to embroidery work, and how it sustains solidarity, as we question the politics and implications of our actions.
\end{abstract}

Keywords: Embroidery, conversation, solidarity, politics, textile, social media 


\section{Setting the story}

We are three women who found each other and connected through collective embroidery and textile responses to recent violence in Mexico. Specifically, this setting was Bordando por la paz y la memoria [Embroidery for peace and memory]. Bordando por la paz is a network of embroiderers across Mexico and beyond, who collectively stitch handkerchiefs naming the thousands of victims of Mexico's so-called "war on drugs" (Colectivos Bordados por la paz, Bordamos por la paz and Bordando por la paz, 2014; Rizzo Reyes, 2015; Olade Rico, 2019; Bordando por la paz Puebla, 2020). These embroidery groups generally take place weekly in a public space, such as a square or a park and, when they began, were simultaneously a way to re-enter and claim public space in the face of violence, connect with others and build community, and document and testify to the thousands of deaths and disappearances taking place (Photo 1). Cordelia and Rosa, both from Mexico, met in 2011 via social media while participating in local groups of Bordando por la paz: Rosa established a group in Puebla, East Central Mexico, and Cordelia was part of a group in Monterrey, North East Mexico, which was principally made up of relatives of people who had been disappeared. In 2015, while in Mexico researching the memorialisation of contemporary disappearance, Danielle, who is from the UK, was introduced to Cordelia and Rosa. She embroidered with the Bordando por la paz collective in Mexico City and visited Cordelia and Rosa in Monterrey and Puebla to learn more of their experiences. Upon returning to the UK, Danielle brought handkerchiefs from Mexico City, Puebla and Monterrey to be part of the exhibition Stitched voices in Aberystwyth Arts Centre (Andrä et al., 2020; Stitched voices, 2020) and organised regular embroidery sessions in Wales (Photo 2).

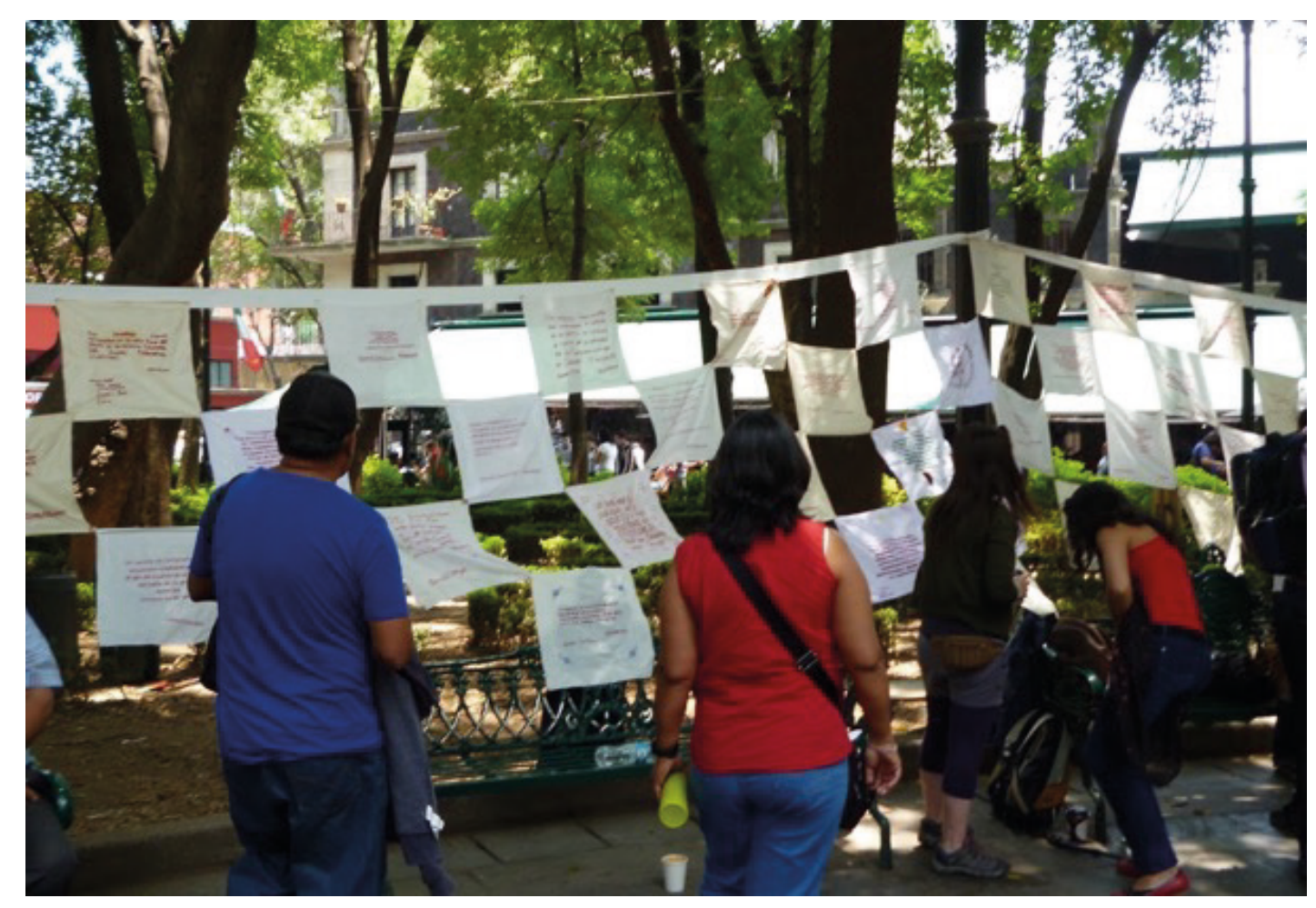

Photo 1: House, D. (2015) Bordando por la paz in Mexico City [Photograph]. Personal collection. 


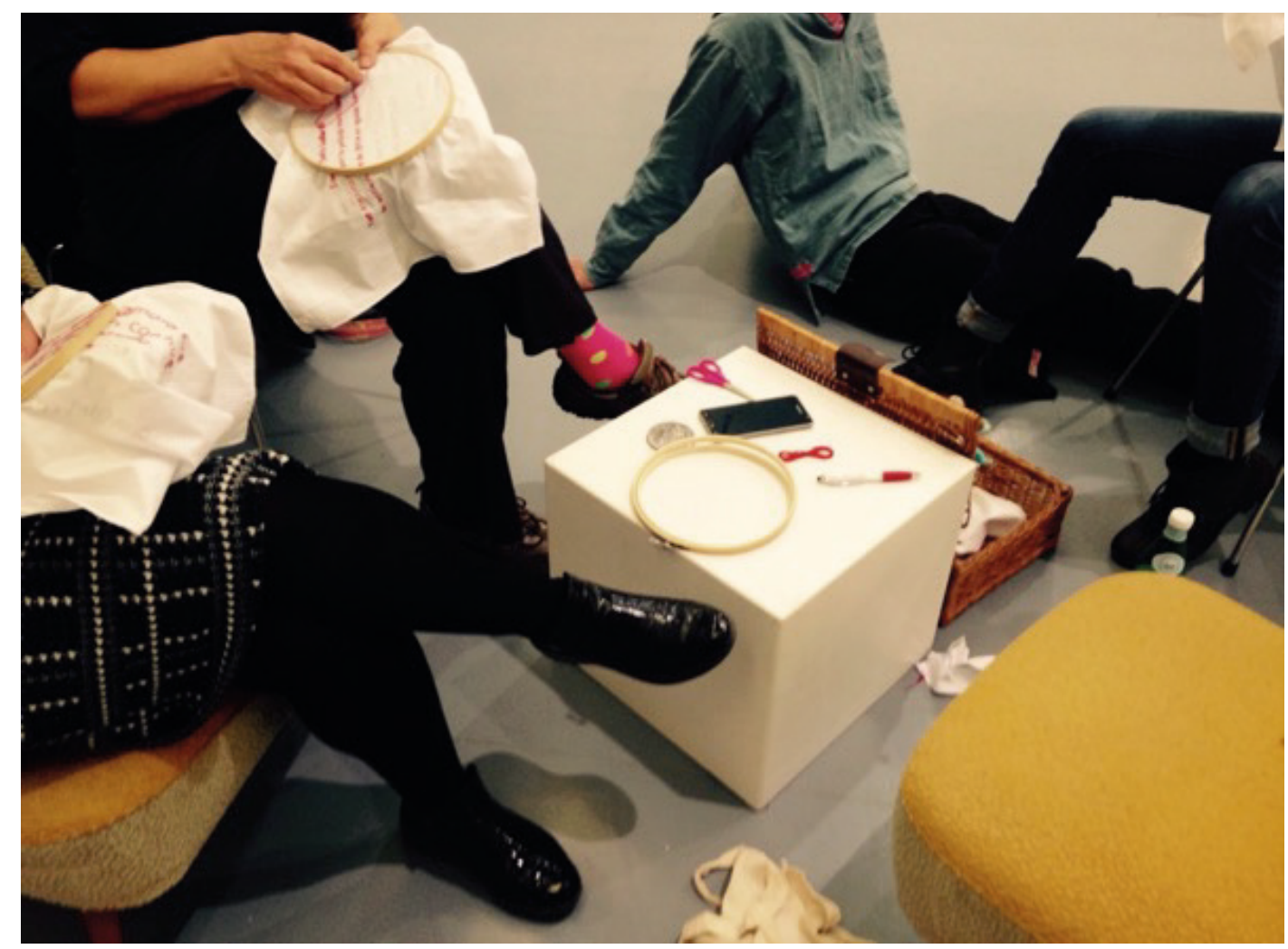

Photo 2: House, D. (2015) Embroidering at the Stitched voices exhibition [Photograph]. Personal collection.

In our own ways, we have each remained connected to the efforts of Bordando and to what it embodies, although participation in the project has, for different reasons, waned for each of us. Alongside Bordando, we embroider as a practice of personal expression and in collective solidarity projects across the world. Since November 2018, we have shared a WhatsApp group where we stay in touch about all aspects of our lives, textile work, and textile responses to social injustices and politics. The group's name is simply Nosotras ("us" or "we" in the female). In January 2020, the conversation focused on exploring questions that we were each forming. We saw a proliferation of textile projects on social media coming both from communities responding to their violent realities, and international communities in solidarity with other more distant but connected struggles. Examples included two projects in which Danielle and Rosa were each participating: 25 million stitches ${ }^{1}$ and Patchwork: healing blanket / La manta de curación. ${ }^{2}$ Our sense that we were witnessing a proliferation led us to deepen our questioning of our own actions: why responding through Bordando por la paz and other textile projects was the medium we turned to, what it meant emotionally to us and to those we were collaborating with, and how we navigated and continue to navigate changing contexts. Guatemalan K'iche' scholar Gladys Tzul Tzul (2018, p. 406) writes that ' $\mathrm{t}$ ] he strategies we use to obtain the means and the resources to weave the threads of our personal lives come from our experiences and from sharing communal goods'. Hence, as producers of textile work, we are also questioning what it means for these intimate projects to be visibilised in the world through social media or other means, and the work they do as they move further, spatially or symbolically, from the people and communities they represent. 
As addressed by this special issue, embroidery is used as a medium for the expression of experiences that are often marginalised (Hunter, 2019; Andrä et al., 2020). Like sewing thread onto fabric, conversations that occur in private spaces also weave an expression of political concern that builds on the work of embroidery. The dynamic relationship of embroidery and conversation relies on ongoing contact, which is why some participants of embroidery initiatives have turned to social media and digital communication platforms to sustain their dialogues and work. As women who have practised this, we have found that these digital conversations and textile practices cultivate solidarity and develop political capacities across space and time.

In 'The uses of the erotic', Audre Lorde (1984, p. 40) claimed that women's experiences and emotions are powerful tools of resistance. Embroidering as a practice tacitly speaks to how important it is to utilise feminine labour to cast light onto the minutiae of the work of political transformation and solidarity building. It can also strengthen awareness of how easily the tools we grow fond of as activists can be used against us, as Lorde argues in 'The master's tools will never dismantle the master's house' (1984). In Lorde's case, contribution to solidarity building centres conversation on a kitchen table, which she views as a powerful political event. Lorde was part of Kitchen Table Press, a literary and activist venture she founded with Barbara Smith and other feminists of colour. Smith mentions that ' $[\mathrm{w}] \mathrm{e}$ chose our name because the kitchen is the center of the home, the place where women in particular work and communicate with each other. We also wanted to convey that we are a kitchen table, grass roots operation, begun and kept alive by women who cannot rely on inheritances or class privilege' (Smith, 1989, p. 11). In line with Lorde's call to break silence and 'be in contact', social media platforms play an important role as a medium for solidarity, akin to how a kitchen table places relating and feeling at the centre of collaborative communication.

What follows are excerpts of our WhatsApp conversation across time, space and social change, which reveal our exploration of these questions. These excerpts reflect the way in which they took place: often rapid outpourings, each of us leaving voice messages while sharing immediate thoughts, at times followed in succession by responses and at others followed by weeks without communication. Alongside our conversations on embroidery, our lives in different corners of the world and time zones - Rosa in Puebla, Mexico; Cordelia in Chicago, USA; and Danielle in Bristol, UK - weave in sustaining our solidarity and friendship.

We take Adrienne Rich's (2001) metaphor of the tapestry to examine what lies behind the side of textile work meant to be seen. Embroideries also have a B-side, where the knots are tangled and undone, and where we see the work that supports the achievements of the network. Much of it is feminised, invisibilised and often thought to be secondary to the achievements themselves. Creating space for these insights within IR contributes to approaches that move beyond the discipline's traditional settings: a focus on the everyday (e.g. Guillaume and Huysmans, 2018), aesthetics (e.g. Bleiker, 2018) and feminism (e.g. Enloe, 1990) within 
international politics and conflict. As often occurs with conversations in the kitchen, our observations take us to cite other conversations and events, bringing in the contexts, both local and global, within which we live. Like the diversity of threads that are fastened in the cloth with the repetitive motion of the needle, these other spatialities and temporalities are woven in, showing that solidarity also lies in the colourful needlework of transnational conversation.

\section{Conversation}

\section{Sunday, 26 January}

After sharing links and photos of a couple of collective embroidery projects we are participating in, the conversation turns to questioning the purpose or helpfulness of these projects. We are each feeling mixed about our participation in these, not hugely motivated or inspired by them, and wondering what is different about these projects to Bordando por la paz: whether it is the projects that are different, or if it is us or the context that has changed.

Rosa audio: I mean I think it's important and it helps, in the case for example of Bordando por la paz, it helps the families of the missing people or all of the assassinated people, it helps them to know they're not alone, so it's a more direct action. But I wonder if we need to do now some other kind of action. Because we have been embroidering for so long and nothing is changing. And so it gets like, gastado. ${ }^{3}$

Dani text: And the problem is without context, all textile responses can look the same and the truly transformative ones can be made to seem bland.

Rosa audio: I'm sorry I'm going to talk because it takes me a long time to write. So, what I was thinking is exactly that. The concern with the weekly presence of Bordando por la paz in plazas is that the handkerchiefs become part of the landscape. And that worries me. Because then it's like a way of life. And handkerchiefs can't become a way of life. Handkerchiefs and embroidery can't become your life because then they lose their true meaning. That's my opinion of course. And so I'm questioning a lot about this stuff. And um, I don't know, I get worried that now embroidering is fashionable. It's like feminism, it's fashionable. And so, I don't know, I have a lot of doubts lately. And I'm sorry if I sound too amargada, ${ }^{4}$ but it's something that I've been questioning a lot, I don't know.

\section{Friday, 28 February}

A month goes by where we do not chat, then Dani gets in touch to say she has submitted abstracts to a journal and a conference on behalf of the three of us, to share these thoughts and conversations. Rosa replies and also wants to share some connections she had just made from a seminar she attended on The politics of silence to the conversation we had had a month ago. 
Rosa audio: I'm still trying to organise my ideas. But I think the risk that collective embroidery projects that are shared online face is the same as other forms of protest when they become massive. It becomes part of the normal life. And I think protest should be always visible. So we have to keep reinventing these ways of making a protest. It's protesta, no, in Spanish. And so I think besides what I told you before, Bordando por la paz is at a different moment. So it needs to be brought up or continued in a different way. And like Cordelia says it doesn't need to be fixed in time or space. And that gives us a freedom. And what is happening is there is a special need for embroidering in groups which is the need to embroider for the missing people, no, para las personas desaparecidas en Puebla, ${ }^{5}$ and also we have this feminicidio, ${ }^{6}$ but it has been, how can I say, there is so much to embroider that it is not possible to keep track of it.

Rosa explains that the group in Puebla have temporarily paused their embroidering because in 2020 they are embroidering cases of femicide from 2017 and they cannot keep up with the deaths. She feels the effort has become useless because it has lost its ability to be an immediate response to the crisis. This leads us to discuss knowing when to stop or change an action.

Rosa audio: The handkerchiefs can become like an archive, but we need to do things more immediate, like an emergency response. And I think this is what's happening with many of the groups, or women who are joining together, even not as a collective but just to embroider together, because it's a reaction. So the protest through textile acquires a different quality. And I think it's valid. It's valid. But on the other hand it becomes background noise. This is the connection that I was, I mean, all of this to make this connection between silence and the power that silence has in our protests. Before, Bordando por la paz was very silent in the sense that although we were noisy outside on the street, the process and the action of embroidering was silent. And it was a process with ourselves - with the person who was embroidering - and the victim. And now when it becomes a protest, it's like an escape for the rage. Rage, is that how you say, la rabia.

Cordelia audio: Hi, I'll also leave a message, so I've been, I think what Rosa is gesturing to is like a dead end, on behalf of what Bordamos por la paz sort of performs, and a certain risk in political protest that is not only a problem to embroideries but also has something to do with hashtags, something that is happening with women's strikes in Mexico like people appropriating stuff, people sort of tweaking protests to make them seem deceiving, like right-wing groups misappropriating forms of protest. And what I keep seeing and what I am also reacting against, is the fact that there is so much taken for granted about what happens when one is in the public square. What I've tried to do when reflecting on what happened with Bordamos por la paz is decentre what we've already seen and try to interrogate it, to try and see what happened in the midst of nothing happening that allowed a lot of people to become a network, back when the project was beginning. Back when people like [name] 
who had no experience in activist groups made the group in Guadalajara grow so big. Back when Rosa was bringing so many people together because I do think that part of how Puebla worked in those first months, and how it was so successful in interpellating people in the square, is because of Rosa and her leadership. And not wanting to make it like if Rosa is not there nothing happens, but there is something special that did happen. And there was also a need to move on which I respect very much. So I believe that there is a lot to be interrogated in that respect as to why people stopped embroidering or why it doesn't make sense to do so anymore, because other types of actions or other types of performances or protests need to be taken up. Or because it has done its work, like Mary Poppins, I mean Mary Poppins doesn't stay with the Banks' family forever, she stays until something important is learned. So I want to see what is learned.

\section{Saturday, 29 February}

The next day the conversation continues.

Dani audio: Hi guys, it's late here and I'm just going to bed and I finally found time to listen to the last two messages you left Rosa and also Cordelia to yours. Regarding knowing when is the time to take up these actions and when is the time to stop or adapt, it's like having the emotional and social intelligence, and reflexivity, to know, to be constantly questioning why we're doing this, what direction it's going in, what, how are people responding to it, are they still responding the same way, has the context changed, is the world different now. And you need to be constantly doing that in order to not become as you say Rosa, like, kind of a part of the furniture. Or as you said Cordelia a refusal even to move the handkerchiefs and the embroidering to a different corner of the plaza. And also for you as people, the people involved need to take breaks sometimes, they have energy at some points and no energy at some points, and that's something also that I learned from [name, a mother searching for her disappeared son, who embroiders] and talking to her about her constant struggles. It's very nuanced. And yeah, those contexts can change, and you have to be aware of those changes when they happen, and I think you two are both brilliant at doing that.

\section{Tuesday, 3 March}

A few days later we chat about an article Cordelia has written and an exhibition Rosa has been to (Photo 3), and we share back and forth photos and links related to this. We are chatty and light and the conversation is less focused. 
Photo 3: Portrait of Chilean artist and poet Cecilia Vicuña, holding a banner she made, exhibited at a retrospective of her work in Mexico City, which Rosa visited and shared. Borrás, R. (2020) [Photograph from Cecilia Vicuña: veroír el fracaso iluminado at the MUAC (Museo Universitario de Arte Contemporáneo), February-October 2020]. Personal collection. Original portrait by Dugger, J. (1974) Chile vencerá.

\section{Friday, 6 March}

Afew days later Rosa gets back in touch. Having re-listened to some of our messages, she had more thoughts to share about the communities and relationships - friendships that are built through embroidery projects, and how this is an important part of the power of these projects.

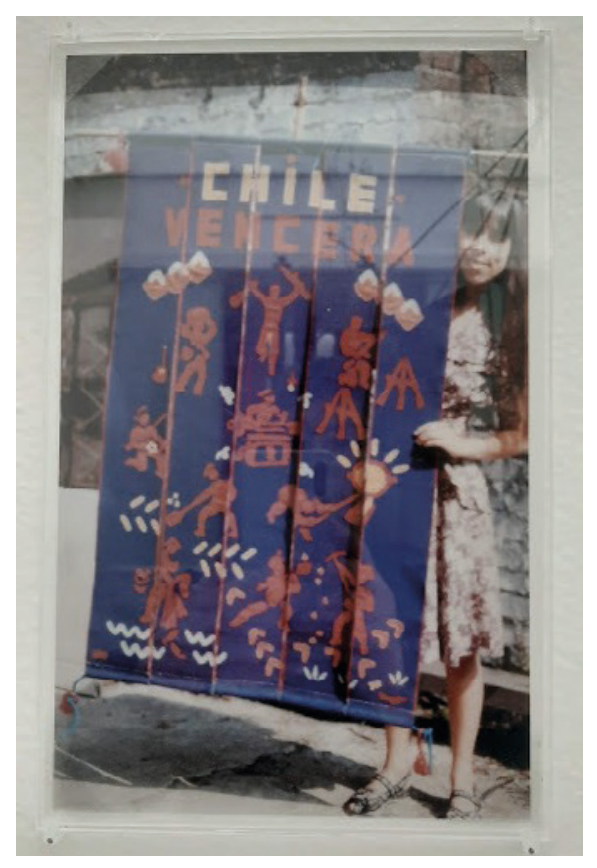

Rosa audio: Also I think Cordelia, what you say about networking through textile work, well it's very interesting because all the people that embroidered in Puebla became so strongly attached to each other, we developed this love, warmth. Loving and warm relationship. And still when we meet by chance or at another event we hug so strongly. We give each other such big hugs, you know, and we respect each other so much and we know that we are there if one of us needs anything, we know that we count on each other. So we know we aren't alone. I think that's very important of these embroidery happenings, as Cordelia calls them, it's to not feel alone.

Dani audio: Hello, when I was cycling home I remembered something I was going to say which was just to say on my own practice of embroidering and doing things, when I was doing the Stitched voices exhibition it made so much sense to me to take Bordamos por la paz and do it in Wales, to sort of contribute and mirror that and there was a group of people. And since I've moved to Bristol, I keep an eye out the whole time looking for the right moment or the right way or the right people to do something similar, but it just hasn't materialised. And I think that's ok, I'm ok with not trying to force something to happen but for it to be the right response at the right time with the right people, and I guess I've learnt that from you both and your experiences.

Ten days pass by and by 16 March the Covid-19 pandemic had become very serious in Europe, including the UK and the USA. Our conversation turns to this and on each other's well-being. Embroidery takes the back seat to caring for one another. On 2 and 4 April, and on 24 and 25 May, we have short conversations checking in with how each other is doing in lockdown in the USA, the UK and Mexico. We share links to embroidery projects, photos from our personal lives, and also discuss issues around the pandemic that connect to the activism and memory work we have done before. We discuss the killing of George Floyd 
in the USA and the wave of Black Lives Matter protests it triggered. But there is a silence between us during the intensity of the first wave of the pandemic, which is taking over our time and energy, and it is hard for each of us with our respective lives and challenges to continue the conversation.

\section{Friday, 29 May}

Dani shares that our abstract for this special issue had been accepted and explains the way forward and her thoughts. Rosa leaves a message to share some of her recent thoughts about embroidery and responding to the pandemic.

Rosa audio: I just want to say that I've been thinking how it doesn't matter what happens with embroidery on a daily basis, but it is something that for me is a necessary thing to do, it's an unavoidable task, and I think a lot about Bordando por la paz Puebla and I think a lot about being, continuing embroidering collectively, and I think after the pandemic it will be a nice time to do it again, as a way of reuniting. So I have to still figure out how, and not to do it by myself again everything, but I think it's a similar crisis in a way, to the one we had in 2012 around the "war on drugs" in Mexico and violence. It's not the same but it has this need for people to get together I think, so I will see how things develop in Puebla, and maybe I can start las convocatorias ${ }^{7}$ again and ask people to join a little team, even if it's changing from time to time. Because people have been asking a lot about it, and I think there's a renewed interest. 
Rosa shares photos of a textile piece she is starting for George Floyd and Eric Garner (Photos 4 and 5).

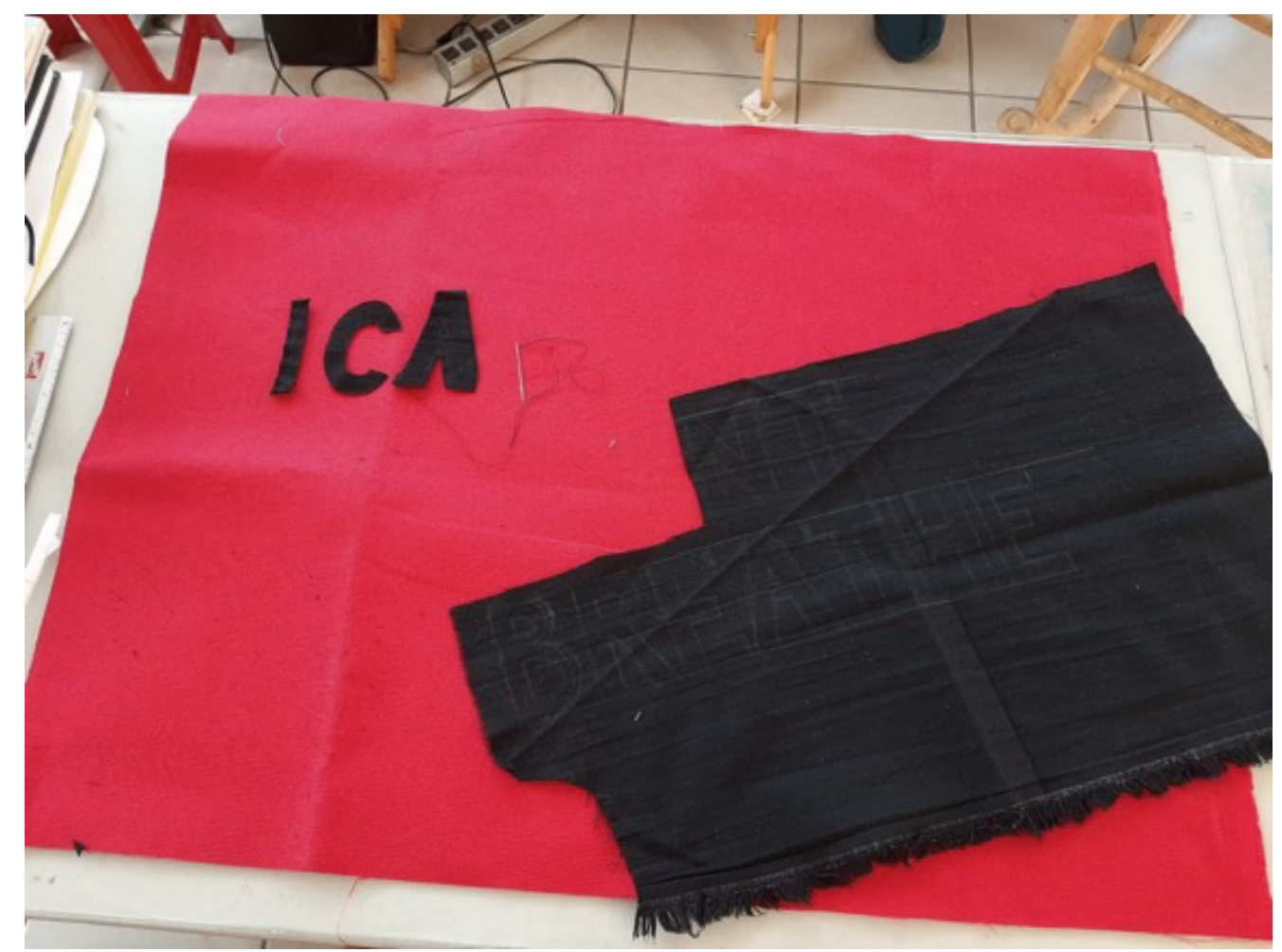

Photo 4: Borrás, R. (2020) Beginning of George Floyd and Eric Garner quilt [Photograph]. Personal collection.

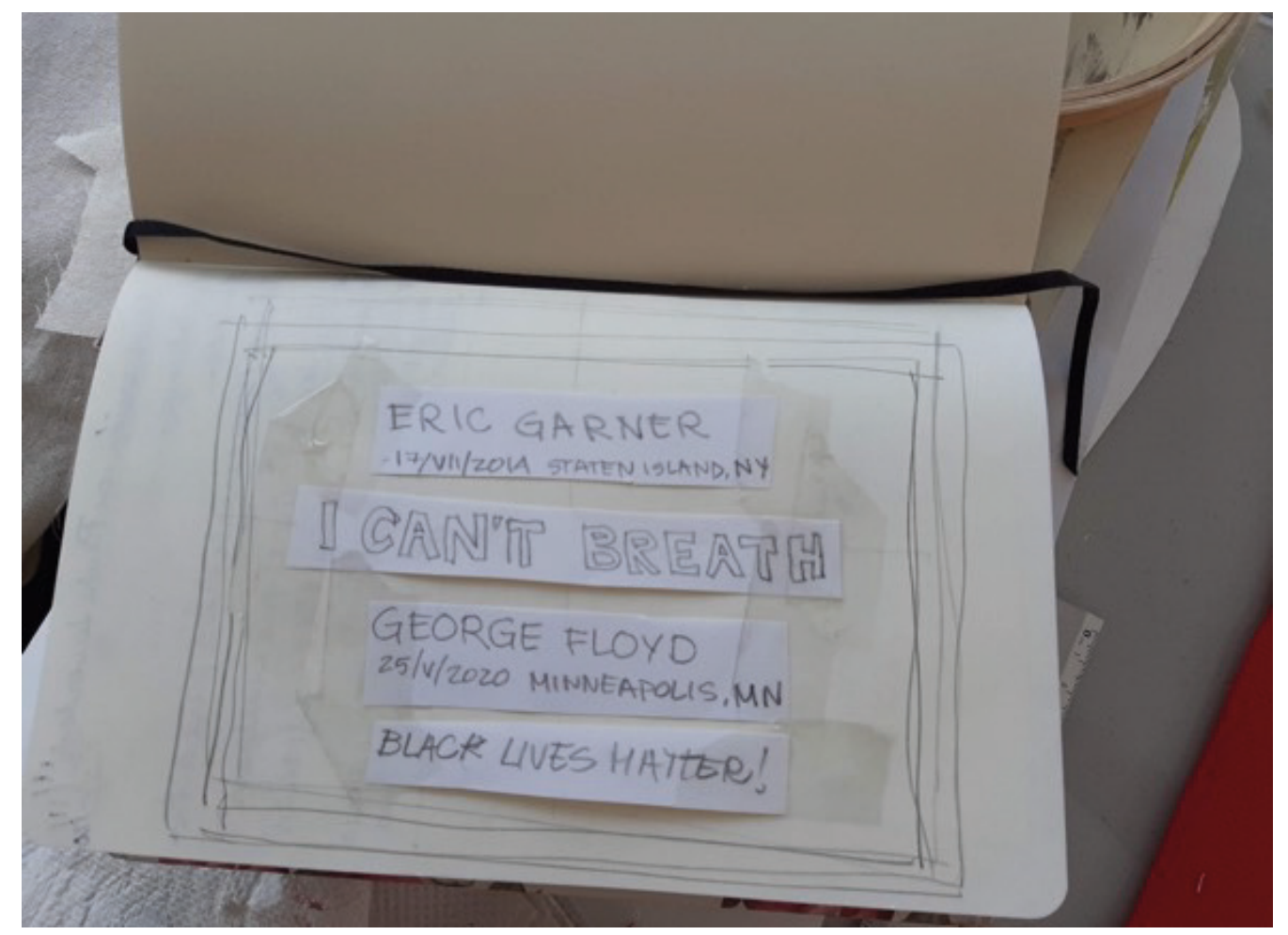

Photo 5: Borrás, R. (2020) Design for George Floyd and Eric Garner quilt [Photograph]. Personal collection. 
Rosa shares a link to an interview with her that will be on the radio.

\section{Tuesday, 9 June}

Ten days or so later, Rosa shares links to another collective embroidery action she has been invited to, which provoked more discussion about the affective nature of turning to embroidery to help process difficult moments and embroidering to explore emotions privately and how this works in tension with solidarity and community.

Rosa audio: And I just thought it would be good to keep our discussion about sewing and collectivity, or colectividad no se como se dice, si collectivity es la traducción. ${ }^{8}$ I think it's very strange to me, it's very surprising and strange, how with this pandemic and confinement, every time people are doing more projects about the pandemic and the confinement. How do you feel, how are you managing, how are you coping, what are your thoughts? And I'm sort of worried about it, because I can't articulate yet with precision why, but I think that we lack the ability in this contemporary world, to accept confinement, and to accept massive loss of this kind. And I think we, we are apparently thinking of the community and the world and of changing the world, but I think that deep inside it's a thought that is me me me, how I'm thinking, how I'm coping. And it's, no sé, me disconcierta. ${ }^{9}$ Because these collective works, or these group works, are in the end, how do I express it, not about the community but about the individual. Anyway, I don't know if that makes any sense to you or what do you feel, I think it's much more interesting what Cordelia was doing in the beginning, which was more a very private and intimate work, writing and embroidering words and trying to figure it out by herself, and then sharing it (Photo 6).

Cordelia audio: Hi to the both of you, you always bring a lot of sense and light into my life, and a lot of warmth as well. I'll keep it short but I want to keep on going, because Rosa's message just struck a chord. I am also just reading some ethnographies on globalisation and global action and you're making me think very much about these other vectors of affectivity that have to do with really being. I mean, to really explore what is very close to you and like a generic quilt might not have the same affective potency as a very personal, very circumscribed form as the arpillera $^{10}$ or as the simple instruction of embroidering letters or something like that. So I think it's very interesting that Rosa you are thinking about this so much, and I also agree that a lot of the testimony is about individuality and not about the communal. 


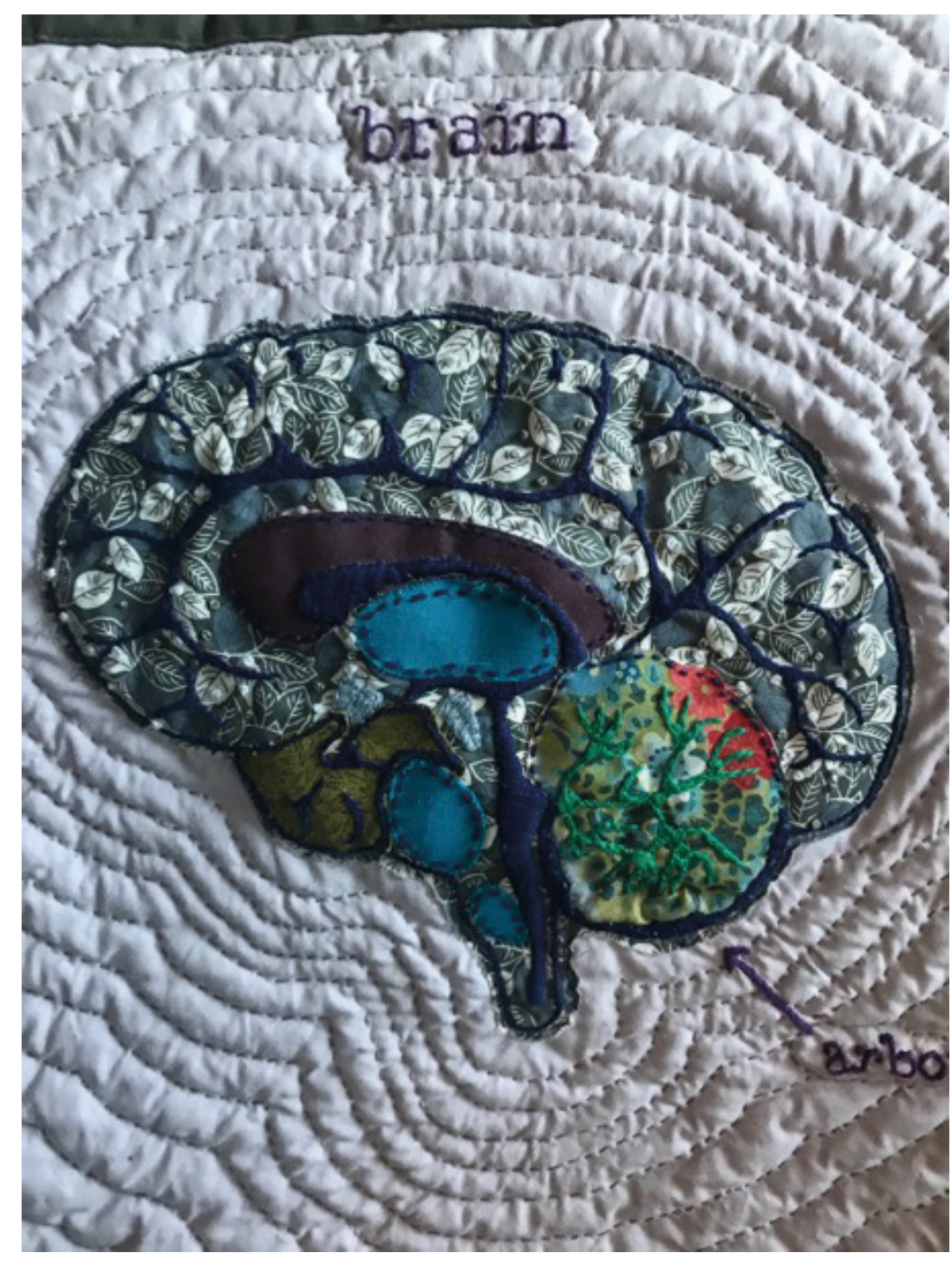

Photo 6: Rizzo, C. (2020) Detail from a quilt made by Cordelia Rizzo in response to the pandemic [Photograph]. Personal collection.

\section{Wednesday, 17 June}

After another week Dani responds, apologising that she has not been engaging in the conversation and, more specifically, a link to another project Rosa shared, which was inviting people to participate in a collective embroidery project, which Dani was avoiding looking at.

Dani audio: It's both personal, how intense lockdown has been with work and a young toddler, but also that straightaway gut response, at least for me, that this embroidery project that Rosa shared isn't what I need, and I don't have the capacity to be giving in this way at the moment and doing these things. And I think Rosa when you said how Cordelia responded in the beginning of the pandemic, I completely understand that, I can understand doing an introspective reflection and working out your own responses and feelings towards it before, rather than just reaching out immediately to this relatively superficial, if that's not too harsh a word, global or international response. Sometimes we actually need to gather ourselves a little bit, work out how we're feeling, how we're doing. And just be dealing with our own immediate communities before being able to engage or think on a different scale. And then there are other times when engaging or thinking on that scale, the international or the global or whatever, is completely instinctive and it just works. 


\section{Not the end}

Our conversation, of course, continues. As Audre Lorde and Barbara Smith argue, the hands that sew keep political actions alive. They challenge us to remain observant, yet open, to the trajectories social mobilisations take, and to find ways to form community and remain in touch through the kitchen table of social media. Our exchanges in WhatsApp weave together personal and international politics with the temporalities and spatialities of the contexts in which we live. Without providing answers, we explore and question our actions: why we respond to international politics through textile and embroidery; how we have and continue to navigate changing contexts that in turn change the meaning of the work; and what it means for these intimate and material objects to be visibilised in the world through social media as they move further, spatially and symbolically, from the people and communities they represent. In these excerpts are threads of conversation that reveal how contexts and meanings change, how the pandemic has shaped possibilities for embroidering collectively and for connection, and how personal capacities are intimately a part of the possibility of embroidery.

Politics, like threads, traverse us, and our intellectual capacity to discern and critique larger scale politics is fed by affectivity: emotion sharpens the value of what we knit together through our words. We pay attention to how embroidering, collectively and personally, has felt, in order to understand some of what these actions and objects mean as they move from their original space and time into others. And it is social media, in this case WhatsApp, that has enabled and sustained this conversation, and our friendship and solidarity. Thus, with this piece, we honour the work conversation does for political projects. Through these conversations we sustain these emotions, reflections and connections in the ongoing work of embroidery.

1 https://www.25millionstitches.com

$2 \mathrm{https}: / / \mathrm{www}$. facebook.com/lamantadecuracion/

3 [worn out]

4 [bitter]

5 [for disappeared persons in Puebla]

6 [problem of femicide].

7 [collective embroidery sessions].

8 [I'm not sure if collectivity is the translation of colectividad [it is correct]]

9 [I don't know, it bothers me]

${ }^{10}$ A form of political textile from Chile, see Andrä et al. (2020). 


\section{Bibliography}

Andrä, C., Bliesemann de Guevara, B., Cole, L. and House, D. (2020) 'Knowing through needlework: curating the difficult knowledge of conflict textiles', Critical Military Studies, 6 (3-4), pp. 341-359.

Bleiker, R. (2018) Visual global politics. London: Routledge.

Bordando por la paz Puebla (2020) [Online]. Available at: https://bordandopazpuebla. wordpress.com (Accessed: 15 August 2020).

Colectivos Bordados por la paz, Bordamos por la paz y Bordando por la paz (2014) Bordados de paz, memoria y justicia: un proceso de visibilización. Guadalajara: Grafisma Editores S.A. de C.V.

Enloe, C. (1990) Bananas, beaches, and bases: making feminist sense of international relations. Berkeley: University of California Press.

Guillaume, X. and Huysmans, J. (2018) 'The concept of "the everyday": ephemeral politics and the abundance of life', Cooperation and Conflict, 54 (2), pp. 278-296.

Hunter, C. (2019) Threads of life: a history of the world through the eye of a needle. London: Sceptre.

Lorde, A. (1984) Sister outsider: essays and speeches. Berkeley, CA: Ten Speed Press.

Olade Rico, K. (2019) Una víctima, un pañuelo. Bordando y acción colectiva contra la violencia en México. Ciudad de México: Red Mexicana de Estudios de los Movimientos Sociales A.C.

Rich, A. (2001) Arts of the possible: essays and conversations. New York, NY: W.W. Norton and Company.

Rizzo Reyes, A.C. (2015) 'Comunicando un mensaje complejo: bordando por la paz y el derecho a la memoria', Derechos Humanos México - Revista del Centro Nacional de Derechos Humanos, 25 (10), pp. 145-176.

Smith, B. (1989) 'A press of our own - Kitchen table: women of color press', Frontiers: A Journal of Women Studies, 10 (3), pp. 11-13.

Stitched voices (2020) [Online]. Available at: https://stitchedvoices.wordpress.com (Accessed: 15 August 2020). 
Tzul Tzul, G. (2018) 'Rebuilding communal life: Ixil women and the desire for life in Guatemala', NACLA - Report on the Americas, 50 (4), pp. 404-407. 
